\title{
Bruk av butte nåler ved kirurgiske inngrep reduserer smittefare
}

Resultatene fra en ny Cochraneoversikt viser at bruken av butte nåler reduserer risikoen for å spre smittsomme sykdommer til kirurgisk personell sammenliknet med bruk av spisse nåler.

Helsepersonell er mer utsatt enn andre yrkesgrupper for sykdommer som spres via blod eller kroppsvæsker. Hepatitt B og C, samt HIV, er typiske eksempler på slike smittsomme sykdommer. Det er flere måter man kan forebygge eksponering for disse sykdommene på: 1 ) vaksinasjon (for hepatitt B) og 2) reduksjon eller fjerning av eksponering (som å unngå unødvendige injeksjoner, bruke tryggere utstyr, gode prosedyrer og beskyttelsesutstyr).

Risikoen for smitteoverføring ved stikk på kontaminert kanyle er 10-30 prosent for hepatitt B, 3-5 prosent for hepatitt $C$ og cirka 0,3 prosent for HIV-infeksjon. Gjennom meldingssystemet for smittsomme sykdommer overvåker Folkehelseinstituttet forekomsten av sykdommer som spres med blod som skyldes stikkskadeeksponering. Tall fra meldingssystemet viser at i perioden 1992-2010 er det meldt om 14 tilfeller av hepatitt B-smitte etter stikkskader i helsevesenet. Ifølge Folkehelseinstituttet kan typiske årsaker være mangel på vaksinasjon eller at stikkskaden ikke ble erkjent umiddelbart og fulgt opp med posteksponeringsprofylakse. I samme periode er det kun meldt inn noen titalls tilfeller av hepatitt $\mathrm{C}$ blant helsearbeidere der yrkesmessig eksponering ikke kan utelukkes (det må nevnes at det har vært mangelfull overvåkning frem til 2008). Det er aldri påvist overføring av hiv ved stikkeskade verken i eller utenfor helsetjenesten i Norge eller de andre nordiske landene.

\section{HVA SIER FORSKNINGEN?}

Forfatterne fant ti studier som vurderte bruken av butte suturnåler sammenliknet med spisse suturnåler hos kirurgisk personell og fant følgende effekter:

- Risikoen for at suturnålen trenger igjennom hansken reduseres ved bruk av butt suturnål sammenliknet med spiss suturnål

- Risikoen for nålestikkskade reduseres trolig ved bruk av butt suturnål sammenliknet med spiss suturnål

\section{HVA ER DENNE}

\section{INFORMASJONEN BASERT PÅ?}

Forskerne i Cochrane-samarbeidet har laget en ny oversikt over randomiserte studier som har undersøkt effekten av butt nålebruk sammenliknet med bruk av spisse nåler hos kirurgisk personell. Forskerne gjorde systematiske søk i flere databaser, og fant ti randomiserte studier med til sammen 2961 kirurgoperasjoner som de inkluderte i oversikten. Studiene ble utført mellom 1998 og 2005 og var gjennomført i USA, Storbritannia, Italia, Irland, Nederland og Tyskland. Alle studiene brukte butte eller kjegleformet nåler som tiltak og sammenliknet med bruk av spisse eller tradisjonelle suturnåler.

\section{KILDE}

Parantainen A, Verbeek JH, Lavoie M-C, Pahwa M. Blunt versus sharp suture needles for preventing percutaneous exposure incidents in surgical staff. Cochrane Database of Systematic Reviews 2011, Issue 11. Art. No.: CD009170. DOI: 10.1002/14651858.CD009170.pub2.

Skrevet av Marita Sporstøl Fønhus,

Nasjonalt kunnskapssenter for

helsetjenesten

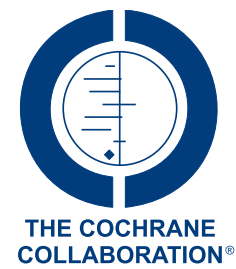




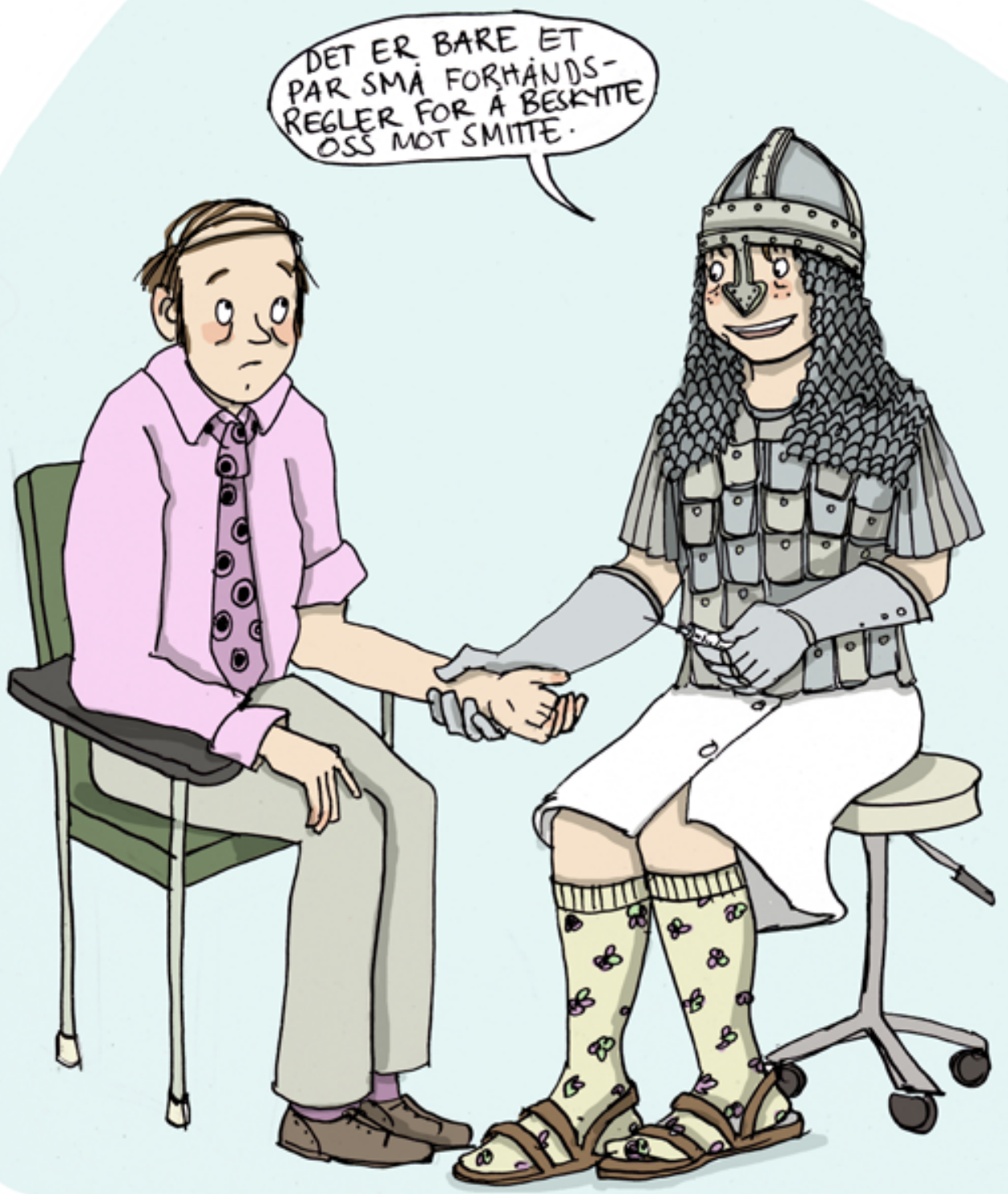

